\title{
Prehispanic flutes, past and future: a revision of the social role of flutes in South America at the XXI century
}

\begin{abstract}
The study of pre-Hispanic flutes from southern Andes (south coastal and highland Perú, highland Bolivia and Argentina, northern to central Chile) shows a special acoustic feature similar to the one used by present day ritual flute orchestras of central Chile. The continuity between both instruments has been established, although present day performances include much Spanish influence (Catholic images, the Bible texts, among others). The similarity between this flute use and another one, the siku of Aymara and Quichua highland communities is revisited, showing both as part of a shared tradition of pre-Hispanic origin. The most complex aspect of this tradition is a kind of polyphonic structure that emerges when many similar flute orchestras gather in a ritual Fiesta at certain dates of the year. The social structure of this polyphonic event shows an special relation between individuals, with social consequences that can be associated with Andean society. The relation between this social structure, present-day musical experiments using it, and the possibility to use it as a tool for understanding our societies is revisited.
\end{abstract}

Volume 5 Issue 4 - 2020

José Pérez de Arce A

Department of Anthropology, Chile

Correspondence: José Pérez de Arce A, Department of Anthropology, Fermín Vergara parcela 6 casa 4, Santiago, Chile, Email jperezdearcea@gmail.com

Received: July 0I, 2020 | Published: August 18, 2020

Keywords: pre-hispanic flutes, southern andes, chinos, musician

\section{Prehispanic flutes}

From about 40 years I have been studying pre-Hispanic flutes from southern Andes (Chile, Argentina, Bolivia, Peru). From the firts approaches, in the 1980s, I noticed that many flutes share a similar structure of the internal tube that shows two internal diameters, one wider in the upper part, and one narrower in the lower part, thus I name it tubo complejo (complex tube). In organological terms, it seems it was intended to produce a special quality of the sound, but iwhat quality was it? This tube appears in different flute types, made in different material, in different cultures. The oldest ones are panpipes with several tubes made of ceramic, described in Paracas culture (700 bc-200 ac.) and in early Nazca (100-400 ac.), both in the dessert coast of southern Perú. ${ }^{1-5}$ Another type of panpipe, almost reduced to one typology of four tubes, provided with a side handle, made of stone, and some made of wood, have been found in the highland of Oruro salt flat, Bolivia, from Yura culture (400-1200), ${ }^{6}$ in Chile, from the northern dessert San Pedro culture (900-1200), the green dessert Diaguita culture (1200-1400), ${ }^{7}$ the central valley's Aconcagua culture (1200-1550), in Argentina adjacent regions from Jujuy to Mendoza. ${ }^{8}$ A later version, with two symmetrical handles appear in Chile southern lake region, in Pre-Mapuche culture (¿1300-1600?). ${ }^{9}$ Resuming, we have a long tradition of a special tube-flute construction that covers many centuries and a great region of southern Andes, whose history I resume in two articles. ${ }^{7,8}$ Stone flutes presents a paradoxical construction dilemma, because it is one of the most difficult material to use for the construction of flutes (specially with a precise bore as complex tube), but this effort does not improve the sound, as all acoustic research made by acoustic specialist Arnaud Gérard prove. ${ }^{10}$ But, thanks to this stone flutes, we have an archeological record in central and southern Andes where organic materials (wood, cane) have not been preserved, because of climate conditions.

\section{Continuity}

Meanwhile, we know that in present day central Chile exist an ancient tradition of ritual flute-dancers called bailes chinos $^{1}$ that uses flutes with complex tube, similar to the prehispanic ones, made of wood. They formed orchestras of many flutes, plus one or more drums. With Claudio Mercado and other investigators, ${ }^{2}$ we began a study of the bailes chinos traditions in Aconcagua valley, near Santiago. The sound of their flutes, that they called sonido rajado (thorn sound), is very different to any other flute sound we know; it is a strong, complex, dissonant and vibrated sound with multiple harmonics and acoustic properties (multiphony, batimiento, dissonance, dynamic vibrato) whose unstable structural characteristics is not easy to describe. ${ }^{11}$ This sound was so strange to European ears that we find not a single description of it in 500 years of colonial or republican writings. ${ }^{3}$

Chinos (as musicians self-define) have a great esthetic value for this sound, they are capable to distinguish many variables, one of whom, named catarra sound, is the most appreciated one, with a heavy vibrato and a penetrating voice. ${ }^{12}$ To produce the sonido rajado, in any of its variants, it is necessary to use a very specific technique, with a heavy and strong blowing, but controlling it so to obtain the lower notes of the register equilibrated with the higher ones. To achieve mastery on this technique, so simple it seems, it

${ }^{1}$ The name baile chino (literally "Chinese dance"), does not refer to the oriental Chinese, but to a colonial word chino, meant service man, given by the Spanish people to Indians in general, and maintained in most of Andean countries till the end of XX century. Present day chinos consider himself as servants of Virgin Mary or other saints.

${ }^{2}$ Project FONCECYT No 92/351, 1992-1993, with Agustín Ruiz, Milton Godoy and other collaborators.

${ }^{3}$ The only mentions found were short phrases that describe the sound as animal ones (birds, donkey, seagull, etc.), not mentioning it as music, not even as a human-produced sound. 
requires years of practice. Claudio Mercado joints the bailes and soon becomes a very good player (I never reach a good sound quality). To make a link between these wooden flutes and the pre-Hispanic stone ones, from the same region, Claudio experiment this playing technique on some archeological flutes. ${ }^{4}$ The result was astounding; the stone flutes, some presumable 700 years old, not only gives sonido rajado, but the best of them, the appreciated catarra sounds. ${ }^{13}$ This is not possible to interpret as a coincidence; it is impossible to match so a specific tube characteristic with so a specific playing technique to obtain the specific catarra sound. Later on, we repeat this same experiment with Diaguita flutes from the Museo Arqueológico de La Serena, the Museo del Limari, and other futes from different Museum and collection, from Mapuche and Atacameño origin, always with similar results. This confirms us that there is continuity between flute construction and, presumably, the same playing technique to sound them.

Present day baile chino tradition extended from Aconcagua to Copiapó valleys, some $600 \mathrm{~km}$ north. They compart the same flute and playing techniques characteristics, with some minor differences (flutes of cane or wood, certain stylistic playing). This region covers a small portion of pre-Hispanic tube complex tradition. North of Copiapó we have not found the complex tube flutes in use. South of Aconcagua valley, the Mapuche Indians still use this flutes, called pifilkas, associated to shamanic practices, ${ }^{9}$ using the paired playing of chino's flutes but not in orchestras, but in dual playing. I will use pifilka name to call all existing one-complex-tube flutes in this article. The complex, strong, unstable sounds of pifilkas are shared by similar sound produced by a lot of Bolivian highland flutes, as wapululus, lawa k'umus, chaqalladas, pinkullus and many others. They show different acoustic structures designed to produce complex sounds, and uses special playing techniques to emphasizes harmonics and multiphonic sounds. ${ }^{11,14-20}$ This confirms that a similar sound esthetics is shared in a wide region of southern Andes, part of which have proofs of it presence during seven centuries or more. But although the use of pifilka among Mapuche people shows a continuity of cultural traits among an indigenous culture (language, rituals, dress, etc), chinos does not show any indigenous characteristic, nor in their language, clothes or any other aspects. They are peasants, or fishermen or miners. In Aconcagua, their proximity to Santiago makes them much occidentalized. History has taught us that indigenous traditions were completely erased in the XVII or XVIII century in this region. When we asked chinos, they didn't recognize any link with aboriginal antecessors, and they thought the origins of their musical practices and flutes comes from king David, as shown in the Bible. Probably they have lost any linkage with their ancestors, due to the colonial practice of erasing every ancient practice and knowledge to be replaced with Spanish Christian ones. Today fiestas de chino rituals happens in Christian dates (the Virgin Mary, Saint Peter, etc.), and the songs refer to these Christian myths. But their music, the production of the sound (playing technique, organological characteristics) and orchestral coordination (sound relations, social relations) are all of local, no-European origin. ${ }^{6}$ Bailes chinos music is based on the strong, atonal and complex sound of the flutes. Flutes are paired; they are played alternately, making an ever-ending complex sound. Many

\footnotetext{
${ }^{4}$ He played two similar Aconcagua flutes, one from the Museo Nacional de Historia Natural and the other from the Museo Chileno de Arte Precolombino (Santiago), with his chino partner, Guillermo Diaz, from baile chino Pucalán. ${ }^{5}$ Today this have change, mainly by the learning they have from Claudio Mercado, who is a chino and also anthropologist and archeologist.

${ }^{6}$ Also, they showed no other influences, as African or Polynesian. A discussion of the permanence of sonic bailes chinos identity see Pérez de Arce. ${ }^{29}$
}

of these pair of different sizes (different pitches at dissonant rate) formed the baile, playing in unison to fuse in a great atonal chord that extend for several octaves, of great intensity, that can sound by hours without pause, because the effort is distributed between pairs of musicians. The main characteristic of these orchestras is to sound as one gigantic instrument, so I called them flautas colectivas (collective flutes). ${ }^{7}$ This music characteristics are the same we found in another indigenous flute orchestras, the sikuriada (a type of panpipe) we found in the highland Titicaca region, among Aymara and Quichua people, thousands of kilometer north from baile chino tradition.

\section{Siku}

The sikuriada tradition has been largely studied, ${ }^{8}$ and we found in it all the main sound characteristics described above (complex sound of flutes, several sizes of not-precise matching, dual chords, unison playing, collective flutes). The siku (flute) is divided in two parts, called ira-arka, each has half of the notes, interspersed between them two. Each sikuri (musician) practices an alternated playing with his partner to produce the melody. Normally sikus are made to produce a complex sound, rich in harmonics, ${ }^{21}$ mostly have palk' $a$, a second row of tubes, made to enrich the timbre. To play a melody, both sikuri must coordinate their blowing so precisely as to be heard as a single musician. All paired flutes in the orchestra plays in unison, as a collective flute, making a dense melody with a dense complex timbre structure, made by the superposition of many flutes of different sizes, and made as not to match exactly, so to produce acoustics alterations similar to the sonido rajado ones. The sound esthetics is not only rooted in the music, but in the structure of sound. ${ }^{9}$

The pre-Hispanic evidence of panpipes in the Andes is well known from 3.000 B.C., and extends from Arica (northern Chile) to Ecuador. Their quantity and variety is greater than in any other part of the world. ${ }^{22}$ We have some good evidences of dual (ira-arka) sikus trough paired instruments and iconography of dual playing, but none is definite, because the only way to be absolutely sure of dual playing is to observe them in the act of playing, interspersing their sounds. We only have this witnessed description from XX century, when this dual technique was observed in the Titicaca region by folklore studies researchers. ${ }^{23-26}$ In the previous centuries we have none description of it, save only one, given by Garcilaso de la Vega ${ }^{27}$ who witnessed, and probably participate in a sikuriada in Cuzco around $1550 .{ }^{10} \mathrm{He}$ describes with detail the dual instrument, the dual playing technique and the different sizes, and declares they were used as a selected music in the court of the Inca, but pointing its origin was not Cusco (Inka's capital city), but Colla (Titicaca) region. Inca politics, based on a complimentary reciprocity system, uses to take preciated aspect of foreign cultures to Cusco, ${ }^{28}$ and music was part of this reciprocity. ${ }^{11}$ From Garcilaso c. 1550 to XX century there is not a single description

${ }^{7}$ Mapuche pifilkas are outside this orchestral playing, thus does not enter on my later argumentations.

${ }^{8}$ A good description of siku tradition can be found in Carlos Sanchez's Música y Sonidos en el Mundo Andino: Flautas de Pan, zampoñas, antaras, sikus y ayarachis, collecting many authors (2018). Also see a classic work on Puno sikuris by Turino, ${ }^{30}$ and a good collection of recordings from Bolivia highland in Baumann. ${ }^{31}$

${ }^{9}$ This is an Andean principle, as we see in textiles, where the beauty does not lie so much in the figure, but in the warp layers and in the combination of techniques. ${ }^{32,33}$

${ }^{10} \mathrm{An}$ analysis of his testimony, among other historic and prehistoric evidence, in Perez de Arce 2018.

${ }^{11}$ In an article Polifonía Imperial I analyze this relation between Cusco and Chile during the Tawantinsuyu. ${ }^{29}$ 
of sikuriada dual playing system. This is not unusual, because normally somebody that doesen't know this technique cannot perceive it from the outside, and in a broad perspective, music playing techniques are associated to a kind of "friendly" type of transmission, that one reserved to family and friends, where you can share melodies, instruments and playing technniques. This kind of transmission was almost absent in America from the invasion time, and the relation between aboriginal people and the state was based on the "war" side of transmission, reserved for the enemy, where you try to destroy any music from the enemy. Indigenous music did not penetrate the cities of Chile, there were no musical instruments, nor tunes coming from Mapuche settlements into urban people, until recent times. On the other side, it has become a custom from Spanish times to denigrate Indian "art", and music among it as part of his "lack of culture". Part of this attitude is based on the difference of aesthetic perspectives, ${ }^{34}$ and also based in a strong desire from mestizo citizens to detach from Indians people. The collective flutes were seen as poor 'barbaric' costumes, and the dual technique was invisible for them. From the 1980 s there is a greater amount of learned sikuris that have begun to describe their practice, and at the same time there are new evidences of pre-Hispanic continuity emerging from different perspectives. . $^{32,35-39}$

If we observe present day sikuriada and bailes chinos traditions, both shows as remaining part of a bigger pre-Hispanic music tradition of complex-sound dual-flute orchestras, that expands in southern Andes. From around 1980 the sikuriada tradition has spread through the continent to many principal cities as La Paz, Lima, Santiago, Buenos Aires and Bogotá, and now this diaspora process reaches other continents as well. ${ }^{40,41}$ The bailes chinos have spread only to Santiago. So, we can observe that this extended collective indigenous flute tradition has extended to no-Indian people..$^{12}$ This is an important shift in social terms, derived from the "friendly" side of relations that, after 500 years, are beginning to emerge in our societies, enabling access to making music or playing instruments. From highland indigenous ritual fiestas to urban Spanish cities the role of these collective flutes has changed a lot, for example from interact with nature to bring the right weather conditions, to become a folkloric show. But there is a social role inside the sikuriada that doesn't change. In any orchestra, the relational system between individuals with different positions and roles is what permits the music to emerge. This can be defined as a sort of society, ${ }^{42}$ and the intergenerational transmission between all participants, old and Young as equalls, proper of sikuriada, is called 'socialization' in sociological terms. ${ }^{42}$ This 'socialization' role is not defined by the sikuris, it is inherent to the orchestra. Inside the sikuriada, thanks to the dual playing that creates a deep bond between the two players, as to make them a single $s i k u^{43}$ this 'socialization' process goes a step forward. This implies an absolute confidence between both, a permanent attentive mood, capable to react instinctively to each nuance in the playing, something that goes beyond normal coordination between musicians. ${ }^{44}$ Sikuris speaks of a musical "braid" (trenzar los sonidos), ${ }^{39,45}$ or to a "question and answer" relation. ${ }^{46-49}$ This instinctive dual playing achieves his maximum level when two sikuris are capable of ornamentate the melody, sharing an instinctive coordinated improvisation, as do the pair of liku cantor in Chile. ${ }^{50-53}$ Also socializing is enhanced because the pair of musicians are accompanied by many others, all of them reacting as a

${ }^{12}$ The sikuriada organollogical and orchestral typology, as I describe it, is present in a vast region, covering ethnic groups from northern Chile to Colombia, and the Amazonian basin, much of these no well described. The aymara and quechua highland tradition is the most dynamic, elaborated and vigorous tradition, from which has expanded, as I describe below. single musician, forming a collective flute. All this process happens as a normal situation, not as the consequence of a rule or external obligation, but as a play among equals. The result, however, does show the internal diversity of the social group, as the sound shows the density of many flutes that doesn't match their tunings exactly, each of whom maintains a certain (minimal) independence of pitch. This kind of social integration, in which nobody excels over others, each maintaining their own identity but merging in the community, as is more important than the individual, is the normal social structure of Aymara or Quichua highland communities. ${ }^{54}$

These social characteristics are emphasized by a tendency in sikuriadas to accept anyone to participate, be it a child, or a person with no special music abilities, or with no knowledge of the melodies. The redundancy of the melodic repetition facilitates the imitation, and also the playing of half the melody makes easier to incorporate. The sikuri knows, and I have experienced myself, that it is easy to join a sikuriada, even if he does not know the melodies or even the style. ${ }^{49}$ This attitude that facilitates the integration with confidence, because the importance is not put into the perfection of the musical product, but on the social experience, is called 'participatory discrepancy', ${ }^{55}$ and is present in many ethnic orchestras around the world. It accepts and integrates the musical error, encouraging the social participation. In sikuriadas, this integration of the error takes a positive role, because if I miss a note and play the next tube, it will sound a Third (because my arka flute is formed by thirds), added to the melody as a kind of harmonic casual ornament (sometimes a pair of experienced sikuris make this kind of ornamentation on purpose). This situation reverses the error into an embellishment, making the newcomer playing even more confident. ${ }^{13}$ During a fiesta that can extend from one to three days long, this 'participatory discrepancy' is always present because all sikuris are moving, touring the place, surrounded by people, sometimes in a drunken state. The overall experience of the joyfull fiesta is greatly enhanced when some of the sikuris reach a strong psychological and emotional state that emerges from the combination of factors, in which the hyperventilation produced by the continuous blowing for a long time iss very important.

When the sikuriada is played on a city like Santiago or Buenos Aires, this 'socialization' role acquires a new dimension. The integrating aspects, dual relation, dissolution of the individual into the group, contrasts vividly with urban tendency to individualism, social verticality, and competence with others. This contradiction acts at an ontological level, changing one's perception of the society. This is not logic, rational experience, but an emotional one. Sometimes the emotion is so great when we finished, that we are unable to speak, and we hug each other, knowing the emotion can't be expressed in words. Many sikuris have related their experience as being part of a "human bellows", ${ }^{49}$ as a group into which "alone we are nothing", ${ }^{44}$ or to perceive a kind of "musical adhesive" between pairs, ${ }^{56}$ a state of profound cohesion and collective integration. ${ }^{43,51,57,58}$ Ontological changes can be so powerful, hat it can change the whole lifestyle on some urban sikuris, as revealed by many personal stories. ${ }^{49,59-61}$ This sociability role of the sikuriada also has been highlighted by many teachers that have incorporated it to the school. The siku has been defined as an "head transforming agent" 62 and their impact on the

${ }^{13}$ Not all sikuriadas allow such "errors", especially some urban ones accustomed to Eurocentric practices. I deliberately emphasize this 'participatory discrepancy' situation because of the important role it has in the 'socializing' role of the sikuriada. For a discussion on this topic, see Turino ${ }^{63}$ and Castelblanco. ${ }^{40,49}$ 
students has been described as promoting responsibility, discipline, collective work, solidarity, respect, tolerance, inclusion, empathy, friendship, compromise, identity, self steem and reciprocity. ${ }^{14}$

\section{Multiorchestal polyphony}

All the above described playing techniques apply to individual orchestras. As collective flute play in unison a melody, when two or more collective flutes plays at the same time during in a ritual fiesta, they act as single flutes, and can combine their individual melodies and rhythms to give birth to a new harmonic, polyphonic and polyrhythmic texture. This special musical form I have called polifonía multiorquestal (multi-orchestral polyphony), that add a new dimension to the experience of participating in the ritual fiesta. During the fiestas de chino in Aconcagua Valley, there is a procession in which all the bailes (sometimes 10 or more), tour the place in a long row, all playing in unison, creating this sort of polyphony. As a musical form it extends in space (sometimes a kilometer long) and in space (one hour or more), and is moving all the time through the place. Each baile plays in complete independence, so the polyphony occurs by the chance of every casual superposition of sounds. It can be heard a very complex and dense timbre structures, with multiple acoustic properties (dissonances, vibratos, timbre instabilities, 'ghost melodies', difference tones, 'dense unison', batimiento, etc.), the sum of the already dense sound of each baile chino. The pulse difference between bailes produces a constant polyrhythmic mutation, so the overall multiorchestral polyphony is an unstable form, but maintaining a great coherence, thanks to some basic rules. The first is the similitude between the collective flutes, their instruments, their sounds, their intensity, as variations of the same topic, and it comes from tradition. The second is that each orchestra must try not to be in the same pulse as any other, and it comes from a very difficult practice. Each baile has a single pulse (so to say, singles quarter notes all the time), but they can change little by little bit speed (more or less fast). When two adjacent bailes plays different pulses, it creates a polyrhythm of dense many-octave dual chords of great intensity. This situation is very difficult for the musicians, because the normal tendency is to merge both pulses. To maintain one's pulse in a chaotic situation, one must follow the tamborero (drummer), who guides with the drum, the gestures and the dancing, and to play as loud as possible, to overcome the other baile's sound. This requires a lot of concentration, and not to listen to the pulse of the neighbor baile. Bailes chinos who can dominate his pulse independence are considered good ones, and there is a strong sense of competence in relation to it. Experienced bailes have tricks to make newbies group loose; they exhibits a paused rhythm, and begin to fasten very slowly his pulse to the point to reach the newbies fast, nervous one. Then both pulses merge in a wonderful, strong and extended unified voice. But then, the experienced baile began to slow their pulse, little by little, and the younger ones that are near follow this change, unnoticed, until the difference with his own baile is so great that they realize have lose their own pulse, and their baile becomes a chaos where no chino can hear the proper pulse, and they must halt for a while, to recompose their playing. Because of this, the multi-orchestral polyphony is referred as a competence, although the loosening or winning are not public expressed. The complex sound density of this ever changing multi-orchestral polyphony is in permanent movement trough different spaces, such as a narrow street between houses that increases reverberance, to the open space of a

${ }^{14}$ This has been mentioned several times as the result of inclusion of the siku in schools. ${ }^{26,35,46,48,59,61,64-68}$ beach or a hill, with no reverberance at all. The acoustic properties of the place take an active part in the overall music form. There are a multitude of sonic situations that are occurring simultaneously, when some of the bailes are reaching the beach, and some are inside the streets, for example. Each person to attend the fiesta can choose it own listening situations and listening sequence. Depending on the position of the listener and the bailes, and the movement or stillness of both, the hearing conditions change. ${ }^{23}$ This creates a kind of 'musical perspectivism', in which the listening experience is a different one for each person. It is impossible to define one musical form, or to define it progression; one can describe as many music as persons are participating the fiesta.

This same sort of multi-orchestral polyphony, with the same characteristics (competition between similar collective flutes, great space and time scenarios, hearing perspectivism) we found in the highland sikuriadas, where it receives several names. ${ }^{15}$ In Potosí it is called atipanakuy, ${ }^{10}$ in Chile contrapunteo ${ }^{58}$ in Charazani choque (Bolivia), and batalla Sonora. ${ }^{16,54}$ It is also conceived as a competition, associated to the Tinku system, an Aymara term that means a ritual battle between communities (later transformed in folkloric dance), ${ }^{69,70}$ an also means meeting, ${ }^{69}$ or match, create balance between opposites. ${ }^{35}$ Sikuriada polyphony is also based on the similar sound between orchestras, their differences are sometimes very subtle, but of great importance for them. This fondness of small contrasts is an aesthetic paradigm for aymara people, who refer to it as "poco varía" (little varies). ${ }^{71}$ I have been experimenting the above mentioned musical principles with Claudio Mercado and other musicians from the 1990s, inside a musical experiment called La Chimuchina. ${ }^{17}$ We apply our investigation on indigenous music onto our contemporary urban performances. One of our experiments has been to reduce the 'free polyphony' concept to few musicians. We use the collective flute logic (grouping similar panpipes, or mohoceños, or tarkas), reducing multiorchestral level to five musicians. For example, if each of us has a siku of four notes, one begins playing a single note in a constant pulse, then another alternates another note, and the rest join on, proposing another pitch, alternating, creating melodies and chords. A melody emerges from the casual combination of the flutes, sometimes a polyrhythm emerges and maintains itself for a while, to dissolve or transform into a new rhythmic situation. At any time, each of us five can change a note, a rhythm, or any combination, but attentive to integrate it in the overall music situation. At any of these changes, the rest can react creating a new combination, staying there for a while till another change is proposed. This state of permanent improvisation maintains all of us alert all the time. The rate of changes can also vary, from a stable relation to a fast-successive transition from one state to other. Each change is a surprise. The music emerges as a communal one, not made by any of us but by the group. The beauty of the music depends on our attention to react and to propone, to give and to receive, to be ready to follow and to guide not only the music but the movement

${ }^{15}$ It has been described in great part of traditional sikuriada occurence; Puno, Conima y Taquile (Perú), Copacabana, La Paz, Charazani, Macha, Arampampa (Bolivia), Iquique (Chile), Huancané, Susquello, Tilcara, Lules (Argentina). ${ }^{16}$ I do not know of other similar 'free polyphonies' around the world. In Sicilia (Italy) Emiliano Li Castro (9/2006) told me about a traditional festival in which several orchestras tour the town, independently, and casually comes near each other, without entering competition. Perhaps this happens in many other places. However, normally the musical discoordination is considered an error due to lack of experience, and is strictly avoided.

${ }^{17}$ With Cuti Aste, Victor Rondón, Norman Vilches, Francisca Gili, Rodolfo Medina, Christian Pino, and many others musicians through 28 years. 
through the place. The rules are very simple, almost impossible to list, the most important one is the mutual knowledge and respect, to maintain one's voice as an indistinguishable part of the whole and always try not to excel. Usually we use this 'free polyphony' style before our concerts, playing it for half an hour or more outside the concert hall (in the playground, or in the street), so when we enter the hall, and the concert begins for the public, we have initiated it a long time before. Then, we do not feels as five musicians, but as a kind of sound-animal that express our feelings, a kind of woven snake that emerges continuously from the relation between each one of us. This animal represents us in this moment, like a sonic mirror of our relations. During our presentations, we enhance the experience using visuals and movements through the place, merging with the public, or to other side, creating an ambience of immersion into the performance. Some listener asks later if we have rehearsed the music, because it sounds so coherent. Normally we end our concerts giving canes tubes to the public, generating an improvisation of a great 'free polyphony', a mass of sound that pulsates in a dual chord, that fills the concert hall, and then walks outside the buildings, to the streets. The euphoric collective enthusiasm shared by this collective music is, as we say, the beginning of the "real" concert.

\section{Polyphony as society}

Any orchestra represents the society, as expressed above. It has been said that orchestra reflect the society or it is a kind of model for it, depending on the point of analysis. ${ }^{72}$ Usually orchestras represent the community they come from when they travel, at many levels; music, style, dressing or performance styles. ${ }^{72-75}$ When an orchestra plays in polyphony, it enacts a specific social representation. Polyphony reflects an interwoven relation between his different voices that in turn reflect the relations that are imagined into the society that create it. The term "polyphony" is frequently used as a metaphor of societal relations. ${ }^{76-78}$ This reference is based on European polyphony, in which two or more voices interact in precise ways, regulated by a written "law" (the music sheet), that express a highly elaborated plan, created in advance by an expert (the composer). Music writing is very useful to this model of polyphony, because it permits the precise planning of each voice-relation with the others; it permits the programming of previous and later movements, following strict harmonic, rhythmic and melodic norms. The study of classical polyphony is mainly based on prohibitions, such as parallel octaves or fifths. The beauty of European Bach's polyphony can be explained as a logical structure that avoids 'wrong' tonal relations. The complexity and precision of this structure is so great, that European orchestras need a conductor to organize it.

This relation between voices is very different to the one described as the 'multi-orchestral polyphony'. If I use it instead of the European one as a metaphor of societal relations, very different kind of social relations emerge. First of all, instead of many individualistic relations roles, we have a cohesive group that has a one-collective role as a single individual that merge with similar ones with different roles. These different roles are not guided by strict rules, but by the absolute independence, the only rule is avoiding coordination with similar groups. There is no need of a high degree of specialization; everyone can fit, no matter his preparation, thus permitting to integrate as many people as you want. There is not a written guide to follow; instead, the relations rely exclusively on an intuitive imitative practice. These societal relations must reflect some sort of Andean societies, but we have no a clear idea of it, because for 500 years we have been told that European type of society, ruled by European polyphonic style of societal relations, is the only valid one, the only real one. In our society, each time it appears some traces of this Andean polyphonic style of societal relations; it is dismissed as a wrong one that must be corrected. When Chilean peasants do not follow strict rules, or strict schedules, they are considered atrasados (late). When a peasant or a poor person does not have a defined specialty he is discriminated, because errors can be not tolerated in a well-coordinated team. When somebody does not know how to read and write, it is an illiterate. A very different appreciation emerges if we consider the opposite, using Andean polyphony as the valid one; then, each time a person follows strict rules, strict schedules, he is losing the experience of being attentive to the world around him, as does musicians all over the world. ${ }^{79-82}$ Each time two or more persons interact in precise ways, regulated by a written "law" they are losing the opportunity to freely dance and play, and to follow the imitative learning process basic to humanity. ${ }^{16,83-87}$ Each time a person follows a highly elaborated plan, created in advance by an expert, he is losing the opportunity to participate in a shared nonverbal experience, to create an experience similar to be crossing a river, "in which you know where to go, but not in a straight line; you accommodate to the river, not the river to you". Each time a person has a high specialty to focus on, he is losing the holistic appreciation of reality into which the self merges with the rest of entities, to the distant hills. ${ }^{5,88}$ Each time a person is reading carefully, he cannot communicate with his companions, hears them, integrate the multilevel social learning process, ${ }^{89,90}$ in which the complete learning curve, from the beginner to the experienced is unfolded ${ }^{78}$ something common all over the world..$^{91}$ All these reversal appreciations of societal relations can seem rude, discriminatory, poorly balanced, unreal. The same can be said about the previous ones that discriminate those who follow Andean societal relations. The only difference is an historical one that has favored European knowledge, and negate local one, produced in our lands.

This last statement is changing at a great speed in our countries. Much indigenous knowledge is emerging all over the population, in many forms and formats. In Ecuador has been formulated a epistemological position systematized in the quechua concept of Sumak Kawsay. In Bolivia the same has happened with the aymara Suma Qamaña concept, both generally translated as Buen Vivir (Good Living), gaining the world's attention for the promoting the Mother Earth Rights. ${ }^{92-97}$ In México Comandante Marcos said "we want a world where many worlds are possible", expressing a claim of indigenous communities from the whole continent, from Mexico to Chile. ${ }^{97}$ In Chile we are discovering the baile chino's music "invisible" to Santiago society for 400 years. In 1960, when I was 10 , I was thought that in Chile there were no Indians. In November 2019, during the uprising events that paralyze Chile, the mapuche banner was leading the crowds, held by non-mapuche citizens.

The sikuriadas and baile chino form part of this change, when people inside the great cities acceded to it experience. Slowly, a new kind of ontology is emerging, that considers local knowledge, local categories, and local logics, some of them not elaborated in a verbal form. Music is an efficient tool to produce ontological revolutions inside societies. There are many tales of sikuris in Bogotá, Buenos Aires and Santiago, whose participation in the sikuriada produced profound transformations, some of them at a crisis level that changes their perspectives of life, of community, of human relations. Claudio 
Mercado describe it own ontological transformation as part of bailes chinos,${ }^{98}$ now expanded lo a growing group of young people from Santiago. Pre-Hispanic flutes, present day pifilkas and sikus can be seen as technologies to transform our ontologies in a way designed by ancient local, Amerindian societies. This technology acts not as a planned strategy, nor guided by a superior mind, but performed as music. In La Chimuchina we have applied the permanent alert state between pairs of musicians to a new urban format. We have learn, from the andean polyphonic style, that it is not necessary to coincide with others, that we can maintain our independence, that it is not necessary to resolve the differences into a common (democratic) equilibrium, that there is another type of stable ecological situation, made of differences that interacts as complimentary parts of a whole. We have learned to create beauty not by planning, but to let the unexpected to emerge as a rule, such as life is. Andean people, as African people too, imagine the future in front of us, because we know it, we see it, we can learn from it, and the future is at our back, we cannot see it, it has not happened yet. We are beginning to figure out that all of our societal history is guided by a future that doesn't exist, and which was imagined by foreigners. We are beginning to see our past, hidden for 500 years, each time a group of children from a poor quarter of Lima brings a new orientation to his life by playing the sikuriada, and each time we use pre-Hispanic flute's replicas in La Chimuchina concerts. Then, a certain ontological revolution occurs, that guide us into our own world. South Andean society is changing, and the emergence of a new ontology into which the indigenous identity begins to be present is the most novel aspect, because it signals a change from the previous 500 years where our main cultural source was thought of Spain and Europe. The present article focuses on a special focus of archeo- and ethno-musicology studies that brings evidence of historical continuity and permits the vemergence of ontologies linked with local, nonEuropean sources. This ontological change can influence the future of the region in ways we can not imagine, perhaps making possible that music and politics combine again, as were in Inca times. ${ }^{99,100}$

\section{Acknowledgments}

Thanks to the many sikuris and people who help me with his knowledge, experience and friendship: Arnaud Gérard, Carlos Sanchez, Victor Colodoro, and so many other impossible to cite. Thanks to chimuchines Claudio Mercado, Francisca Gili, Christian Pino, Rodolfo Medina and all the other participants in this experiences. Thanks to CECLA, University of Chile, to make possible my experiences in Potosi and Lima, and to all who share his feelings through many years about the music as social bonding.

\section{Funding}

None.

\section{Conflicts of interest}

Author declares that there is no conflict of interest.

\section{References}

1. Bolaños César. Las Antaras Nasca. CONCYTEC, Lima. 1988.

2. Gruszczyn'ska-Ziółkowska Anna. Sound and its numbers interpretation of acoustical data from the nasca culture (Peru) Studien zur Musikarchäologie III. Vorträge des 2. Symposions der Internationalen Studiengruppe Musikarchäologie im Kloster Michaelstein. 2000;17-23.
3. Gruszczyn'ska-Ziółkowska. Anna Ritual Dzwieku, Muzyka w Kulturze Nazca. Institut Muzykologii Uniwersytet Warszawski/Pollkie Towarzystwo Stuiów Latynoamerykanistycznych. Warszawa; 2003. 212 p.

4. Gruszczy'nska-Ziółkowska Anna. Masculine Musical Instruments in the Andean Tradition. Symposium of the international music archeology study group in Michaelstein Monastery. 2002. p. 253-260.

5. Gruzinski Serge. The colonization of the imaginary, indigenous societies and westernization in Spanish Mexico, 16th-18th century. FCE, 1991. México; 2004.

6. Gérard Arnaud. Acoustic interpretation of the ayarachi "yura" from the charcas museums. Archaeological days, Archaeological Research Center, Sucre: 2004

7. Pérez de Arce José. Sonido Rajado: Historical Approach. The Galpin Society Journal T. LIII. London: The Galpin Society; 2000. p. 233-251.

8. Pérez de Arce José. Purple Combarbalite Flutes from Central and Semiarid Northern Chile. Bulletin of the Chilean Museum of PreColumbian Art. 2014;19(2):29-54.

9. Pérez de Arce José. Música Mapuche. Revista Musical Chilena. 2007.

10. Gérard Arnaud. Atipanakuy. (CD) Jatun Ayllu, P'otojsimanta. Asociación Kausasun. Potosí. 2002

11. Cepeda Sarah Anhala. Resonant frequencies in complex tubes (acoustic theoretical-experimental study) Thesis to qualify for the academic degree of Bachelor of Physical Sciences, Physics career, Fac. Of Pure Sciences, Tomas Frias Autonomous University, Potosí, Bolivia. 2011.

12. Mercado Claudio. With my humble devotion. Banco Santander, Chilean Museum of Pre-Columbian Art, Santiago, 2003.

13. Mercado Claudio. Con mi flauta hasta la tumba. Boletin del museo chileno de arte precolombino. 2005;10(2):29-49.

14. Gérard Arnaud. Multifonías in Andean aerophones of Bolivia. Bolivian Journal of Physics. 1997;3(3):40-59.

15. Gérard Arnaud. Tara: The Aesthetics of Pulsing Sound - A Synthesis. In: Mundo Florido, editor. Archeomusicology of the Americas Vol.4 Ekho Verlag, Berlin; 2015. p. 43-64.

16. Podhajcer Adil. Jjaktasiña irampi arcampi: emotion and beliefs in La Prudencio. 2015.

17. Sánchez Huaringa Carlos. The PCP-luminous path in the universities, concept and practice of folklore: The "Art of a new type" in the Sikuris. Lima: Centro Cultural de San Marcos; 2016.

18. Sanchez Huaringa Carlos. Music and sounds in the Andean world: Pan flutes, panpipes, antaras, sikus and ayarachis. Universidad Nacional Mayor de San Marcos, Lima: 2018. p. 355-422.

19. Pérez de Arce José. The Collective Flute: The social use of closed tube flutes in the southern Andes. Music and sounds of Latin America: pan flutes, panpipes, antaras, sikus. Lima: Editorial Fund of the National University of San Marcos; 2018. p. 151-206.

20. Stobart Henry, Marino Martínez. Sensational sacrifices. Delighting the senses in the Bolivian Andes. Anthropologica. 2018;36(40):197-223.

21. Gérard Arnaud. Aco-ustics of Andean Syringes currently in use in Bolivia (version 4). Investigation report. Acoustics Laboratory, Physics career, Faculty of Pure Sciences. Bolivia: Tomás Frías Autonomous University, Potosi; 1999.

22. Aguirre-Fernández Gabriel, Damián Blasi, Marcelo Sánchez-Villagra. Panpipes as units of cultural analysis and dispersal. Evolutionary Human Sciences. 2020;2:e17. 
23. Paredes Rigoberto. Art in the altiplano (folklore). Boletin de la Pérez de Arce. 1996.

24. D'Harcourt Raoul, Marguerite D'Harcourt. The music of the Incas and its survivals. Paris: Lib. Orientalist Paul Gethner; 1925.

25. Izikowitz, Karl. Musical an other Sound Instruments of the south american indian. Goteborg: Elanders bocktrickeri aktiebolag; 1935.

26. González Bravo Antonio. Boletin latinoameticano de música. Ed Cooperativa Internacional, Rio de janeiro; 1936. p. 253-257.

27. Garcilaso de la Vega Inca. First part of the Royal Commentaries. Facsimile: Lisbon; 1609.

28. Métraux Alfred. Les Incas. 1970.

29. Pérez de Arce José. Chinese dances and their invisible identity. Revista Chungará. 2017;49(3):427-443.

30. Turino Thomas. Moving away from silence; music of the peruvian altiplano and the experiene of urban migration. Chicago and London: The University of Chicago Press; 1993.

31. Baumann Max Peter. Musich im Andehochland, Museum für $b$ Volkerkunde. Berlín. 1990.

32. Arnold Denise, Juan de Dios Yapita, Elvira Espejo. Hilos sueltos; Los Andes desde el textil. ILCA y Fundación Xavier Albó, La Paz. 2007.

33. Arnold Denise, Elvira Espejo. The three-dimensional textile. The nature of tissue as an object and as a subject. ILCA, La Paz; 2013.

34. Verónica Cereceda. Approaches to an Andean aesthetic: from beauty to tinku. Three reflections on Andean thought. Hisbol, La Paz; 1987. p. $113-225$.

35. Baumann Max Peter. Andean music, symbolic dualism, and cosmology. Cosmología y música en los Andes. Frankfurt am Main, Vervuert, Madrid, lberoamerica. 1996. p. 15-66.

36. Bolaños César. Las antaras y la organología. Folklore. Arte, cultura y sociedad. Revista del Centro Universitario de Folklore UNMSM. 2007;1(1):49-70.

37. Mardones Pablo, Francisca Fernández. Five centuries resisting: the October 12 march in Buenos Aires and Santiago de Chile as a chronotropic collective memory and Amerindian vindication in Abya Yala. In: Yes We Are Americans. Journal of Cross-Border Studies. Iquique: Institute of International Studies of the Arturo Prat University; 2017;17:143-171.

38. Sanchez Huaringa Carlos. The archaeological and ethnographic "antaras" of model "W" in "convergent staircase" or "double staircase"; origins and continuity. Mundo sikuri magazine, 25 years sikuris mallkus May 12, anniversary edition. Sukuris 12 de mayo, Lima: 2017. p. 39-46.

39. Sánchez Huaringa Carlos. Formation and development of the Sikuris of Lima. Sánchez; 2013.

40. Castelblanco Daniel. Blowing sikus beyond Titicaca: sets of sikuris as islands of the trans-Andean cultural archipelago in Buenos Aires, Santiago and Bogotá. Revista de Crítica Literaria Latinoamericana. 2014;40(80):265-282.

41. Pérez de Arce José. A Brief History Of Siku. Presented at the 3rd International Congress of Sikuris in Buenos Aires, Agosto; 2019.

42. Bargield. Anthropology Dictionary. Siglo XXI Editores, México. 2000

43. Turino Thomas. The Coherence of Social Style and Musical Creation Among the Aymara in Southern Peru. In: Romero Raúl, editor. Pontificia Universidad Católica del Perú, Instituto Riva Agüero; 1988. p. 61-96.
44. Vega María Alejandra. An approach to the music of sikus bands in Tilcara and Buenos Aires. Ninth Conference on Music and Musicology, Interdisciplinary Research Conference, Faculty of Musical Arts and Sciences, UCA. 2012.

45. Ibarra, Miguel Ángel. Lakitas: continuity and transformations of a traditional Andean musical practice in the Chilean context. In: Proceedings of the I National - International Congress of Siku. Conains: Lima; 2011. p. 1-18.

46. Avila Braulio, Francisco Padilla. Lakitas in the Classroom. Memory to apply for the title of Professor in Music Education. Metropolitan University of Education Sciences, Faculty of Arts and physical education, Department of Music Education, Santiago. 2002.

47. Stobart Henry. Interlocking realms: knowing music and musical knowing in the bolivian andes. In: H Stobrt, R Howard, editors. Knowing and learning in the Andes. Livverpool University Press; 2002. p. 79-106.

48. Barragán Fernando, Pablo Mardones. Che Sicuri: expression of the siku in the porteño context; Its role in the Aymara-Quechua reproduction dynamics and its constitution as part of the cultural identity of Buenos Aires. T. S. 2013.

49. Castelblanco Daniel. Sikuriando melodies from distant times: the cosmopolitan sikuris and the validity of "the Andean" in Bogotá, Santiago and Buenos Aires. A Dissertation submitted to the Faculty of the Graduate School of Arts and Sciences of Georgetown Universitymin partial fulfillment of the requirements for the degree of Doctor of Philosophy in Spanish, Washington, DC. 2016.

50. Mardones Pablo, Rodrigo Riffo. The Mecca of the Lakita; The participation of the Comparsas de Lakita in the Easter of the Blacks. Buenos Aires: Proceedings of the X Argentine Congress of Social Anthropology; 2011.

51. Ibarra, Miguel Angel. Lakitas: continuity and transformations of an Ibarra. 2016.

52. Mardones Pablo. The Chilean lakita: an analysis from the incorporation of the genus cumbia. Revista Sikuri. 2014;6:4-8.

53. Mardones, Pablo, Miguel Ángel Ibarra. Musical language and Lakite identity: Revitalization and continuity of an ancestral and contemporary practice in the great north of Chile. In: Music and Sounds in the Andean World: Pan flutes, panpipes, antaras, sikus and ayarachis. Lima: Major National University of San Marcos; 2018. p. 325-354.

54. Ajata Elías. Teaching of native languages from their own cultural values. Religiosity: XXVI Annual Meeting of Ethnology Volume I. National Museum of Ethnography and Folklore, La Paz. 2013. p. 471-482.

55. Keil Charles. Participatory discrepancies and the power of music. In: Musical cultures; ethnomusicology readings. Ethnomusicology Society. Editorial Trona, Madrid. 1994; 261-272.

56. Podhajcer Adil. The Andean musical dialogue: emotion and beliefs in the creativity of Andean music groups from Buenos Aires (Argentina) and Puno (Peru). Latin American Music Review/Revista de Música Latinoamericana. 2011;32(2):269-293.

57. Valverde Luis. The dance of the sikuris: creation and recreation of an ancestral Andean dance. Folklore. Arte, cultura y sociedad. Revista del Centro Universitario de Folklore UNMSM. 2007;1(1):315-351.

58. Ávila Braulio. Corps De Cuerpos: the experience of ethnocorporeity1 in Lakita's music. Proceedings of the I Latin American Meeting of Researchers on Bodies and Corporalities in Cultures. Edited by Investigations in Performing and Performing Arts (SNP). 2012.

59. Meme, Cristina. Statement of bond, principles and role of the Sikuris gang, in IMPA, 2006. 
60. Tarrillo Dany. Efecto de La Ejecucion Del Siku en La Socializacion. Folklore. Arte, cultura y sociedad. Revista del Centro Universitario de Folklore UNMSM. 2007;1(1):261-275.

61. Timaná La Rosa Ruth. The sikuri, aymara culture, in a globalized world. Ch'amampi! Vientos del Altiplano por el CEMDUC. Construyendo Nuestra Interculturalidad. 2009;5(5):1-4.

62. Balancino Jorge. The sikuri at school. Presented at the 3rd international congress of sikuris in Buenos Aires3rd international congress of sikuris in Buenos Aires. 2019;14-16.

63. Turino Thomas. From essentialism to the essential: Pragmatics and meaning of the interpretation of the sikuri from Puno in Lima. Revista Andina. 1992;10(2):441-456.

64. López Marcelo Luis. Proposal for the implementation of siku in Machaca. 1990.

65. Acevedo Saul. Los sikuris de San Marcos; historia del conjunto de zampoñas de San Marcos. Alter-Nativa: Lima; 2003.

66. Apaza Añamuro Rubén. The siku in the primary worldview. Folklore, Art, culture and society. Magazine of the UNMSM Folklore University Center. 2007;1(1):31-48.

67. Ajata Carlos, América Zanga. Music, discrimination and ideology. Annual Ethnology Meeting 26, Volume II. National Museum of Ethnology and Folklore, La Paz. 2013. p. 33-48.

68. Calisaya Zenon. The sikuris: globalization and postmodernism. 2014.

69. Platt Tristan. Mirrors and corn: Themes of the Andean symbolic structure. CIPCA (mecanografiado). 1976.

70. Fernández, Francisca. Memories in resistance: festivities and ritualities. In: Fischer Michael, editor. Ethnicity and the Post-modern arts of memory. Writing culture: The poetics and politics of ethnography. Los Angeles: University of California Press; 2018;194-233.

71. Borras Gerard. Poco varia: the sesame of Aymara organology. Latin American music. Strings: CORDAE/La Talavera; 1998. p. 33-46.

72. Turino Thomas. The Coherence of Social Style and Musical Creation among the Aymara in Southern Peru. Ethnomusicology. 1989;33(1):1-30.

73. Turino Thomas. Music as social life: The politics of participation Chicago: The University of Chicago Press. 2008.

74. Kartomi, Margaret. Introduction / Youth orchestras in the global scene / The Australian youth orchestra Inc.: its identity as a national icon and expansion of its performance and educational Programs. En: growing up making music: youth orchestras in Australia and the World. Australasian Music Research 9. Lyrebird Press, Faculty of Music, The University of Melbourne. 2007; XI-XIV;1-26/27-53.

75. Cunha Rosemyriam. Collective musical practice: political and sociocultural implications. 2016.

76. Tyler Stephena. Post-Modern Ethnography: From Document of the Occult to Occult Document. Writing culture: The poetics and politics of ethnography. Los Angeles: University of California Press; 1986. p. $122-140$.

77. Rabinow Paul. Representations Are Social Facts: Modernity and Post-Modernity in Anthropology. En: Writing culture: The poetics and politics of ethnography. Los Angeles: University of California Press; 1986. p. 234-261.

78. Ingold Tim. The life of the lines. Santiago: Editions UA Hurtado; 2015

79. Trimillos Ricardo. Subject, Object, and the Ethnomusicology Ensemble: The Ethnomusicological "We" and "Them". Performing
Ethnomusicology; Teaching and Representation in World Music Ensembles. London: University of California Press, Berkeley Los Angeles; 2004. p. 23-52.

80. Harnish david. No, Not 'Bali Hai. Challenges of adaptation and orientalism in performing and teaching balinese gamelan. Performing ethnomusicology; teaching and representation in world music ensembles. London: University of California Press, Berkeley, Los Angeles; 2004. p. 126-137.

81. Reijonen Olli. Lost Batucada: The Art of Deixa Falar, Portela and Mestre Oscar Bigode. Ph D. thesis Ethnomusicology, University of Helsinki, Helsinki. 2017.

82. Cámara de Landa Enrique. Ethnomusicology ICCMU Madrid. 2004. 572. P.

83. Borrás Gérard. Traditional music and social dynamics among the Aymara people of the Bolivian highlands. Annual Ethnology Meeting, National Museum of Ethnography and Folklore, La Paz. 1985. p. $133-143$

84. Marcus, Scott. Creating a Community, Negotiating Among Communities: Performing Middle Eastern Music for a Diverse Middle Eastern and American Public. In: Performing Ethnomusicology; Teaching and Representation in World Music Ensembles. Berkeley Los Angeles London: University of California Press; 2004. p. 202-212.

85. Cox Amie. Hearing, Feeling, Grasping Gestures. Music and Gesture. England: Ashgate Publishing Company, Hampshire; 2006. p. 45-60.

86. Leman Marc. Music, Gesture, and the Formation of Embodied Meaning. In: Musical Gestures: Sound, Movement, and Meaning, New York: Routledge; 2010. p. 126-153.

87. Schuppli Caroline, Carel van Schaik. Animal cultures: how we've only seen the tip of the iceberg. Evolutionary Human Sciences. 2019;1(2):1-13.

88. Abbot Don Paul. Rhetoric in the New World, Rhetorical Theory and Practice in Colonial Spanish America. University of South Carolina. 1996.

89. Lave Jean, Etienne wenger. Situated learning: legitimate peripheral participation: learning in doing: social, cognitive, and computational perspectives. Cambridge and New York: Cambridge University Press; 1991.

90. Lave Jean. The practice of learning. In: contemporary theories of learning: learning theorists in their own word. New York: Routledge; 2009 .

91. Rozo Bernardo, Alejandro Barrientos, Nicolás Supayabe, et al. New Moon Healings Knowledge, Practices and Musical Products in Lomerio. Bernardo Rozo (Coord.) Disclosure Document. Audiovisual DVD included. Peace. FAUTAPO-ProAa. 2011.

92. Huanacuni Mamani Fernando Buen. Good Living/Living Well. Andean regional philosophy, policies, strategies and experiences. Lima: Coordinadora andina de organizaciones indígenas. 2010.

93. Gudynas Eduardo. Buen vivir: Germinando alternativas al desarrollo. América Latina en Movimiento. 2011;462:1-20.

94. Gudynas Eduardo. Buen vivir: decrecimiento, vocabulario para una nueva era. Barcelona: Icaria; 2015. p. 295-299.

95. Gudynas Eduardo Alberto. Acosta good living beyond development. Lima: Revista Quehacer 181, Desco; 2011. p. 70-81.

96. Acosta Alberto. Alternative development, alternatives to development and good living: items for discussion. Building Good Living. PYDLOS, Cuenca, Ecuador; 2012. p. 33-45. 
97. Escobar Arturo. Autonomy and design: The realization of the communal. Cristóbal Gnecco Translation. Popayán: Universidad del Cauca. Sello Editorial; 2016

98. Mercado Claudio. Music and states of consciousness in ritual festivals in Central Chile: Immense bridge to the Universe. 1993;13(1995):19951996.
99. Bellenger Xavier. The vital breath. 2007.

100. Gruszczy'nska-Ziółkowska Anna. Is Sound the first and last sign of life? An interpretation of the most recent archaeomusicological discovery of the nasca culture (Panpipes) Studien zur Musikarchäologie II. Vorträge des 1. symposions der international study group on music archaeology im kloster michaelstein. 1998;18-24. 